Archive for

Organic Chemistry
Arkivoc 2018, part vii, 0-0

to be inserted by editorial office

\title{
Deciphering the conformation of C-linked $\alpha$-D-mannopyranosides and their application toward the synthesis of low nanomolar $E$. coli FimH ligands
}

\author{
Leila Mousavifar, ${ }^{* a, b}$ Gérard Vergoten, ${ }^{c}$ and René Roy*a,b,d
}

a Department of Chemistry, Université du Québec à Montréal, P.O. Box 8888, Succ. Centre-Ville, Montréal, Québec H3C 3P8, Canada

b INRS-Institut Armand-Frappier, Université du Québec, 531 boul. des Prairies, Laval, Québec, H7V 1B7, Canada

' Unité de Glycobiologie Structurale et Fonctionnelle (UGSF), UMR8576 du CNRS, Université de Lille, F-59000 Lille, France

${ }^{d}$ Glycovax Pharma Inc., 424 Guy, Suite 202, Montreal, Quebec, Canada, H3J 1S6

E-mail: leilyanmousavifar@gmail.com; rroy@glycovax.com

Received 10-12-2018

Accepted 11-22-2018

Published on line 11-28-2018

\section{Abstract}

C-Allyl $\alpha$-D-mannopyranosides were prepared via a variety of routes to determine an optimal route to the $\alpha$ anomers. The relative conformational energies of the key intermediate was evaluated by molecular modeling which showed the conventional ${ }^{4} C_{1}$ chair conformation to be the lowest energy conformer. This finding was also confirmed by NMR and X-ray crystallography. The perbenzoylated C-allyl mannoside was also converted into 1,1'-biphenyl analogues using a palladium-catalyzed Heck reaction. Two of the resulting minor reaction products were co-crystallized with the uropathogenic E. coli FimH. Alternatively, the $K_{\mathrm{D}}$ of the major and expected Heck product was in the low nM range as measured by SPR. Crystal data showed that the C-linked derivatives efficiently bind in the FimH binding cavity near the so-called hydrophobic tyrosine gate.

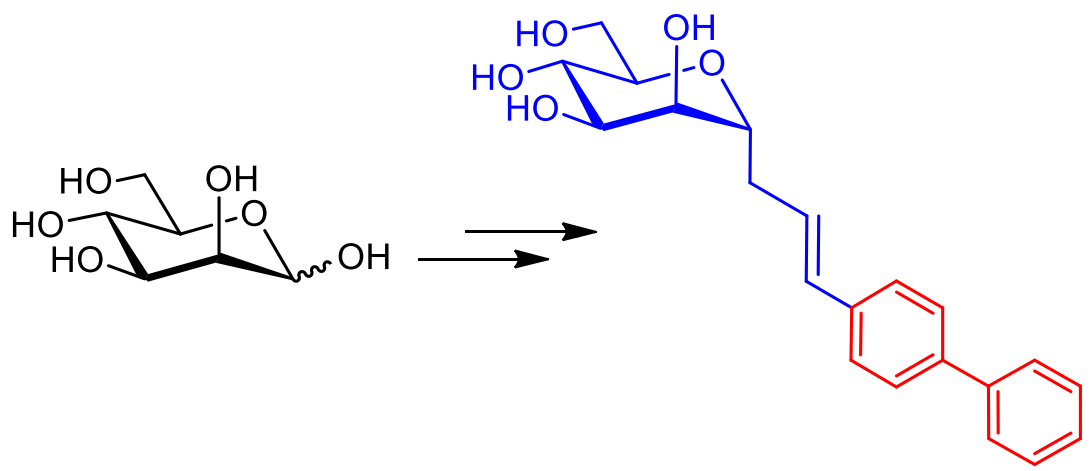

Keywords: E. coli FimH, mannoside, Heck reaction, molecular modeling, X-ray 


\section{Introduction}

Adherent-invasive Escherichia coli (AIEC) infections are a serious health problem for which alternative therapeutic strategies are very timely, ${ }^{1,2}$ particularly in light of bacterial resistance against the most recent arsenal of antibacterial agents. ${ }^{3-5}$ Amongst these, Escherichia coli responsible of urinary tract infections (UTIs), intestinal bowel diseases (IBDs) such as Crohns's disease (CD), and ulcerative colitis constitute major challenges for medicinal chemistry. ${ }^{6,7}$ Uropathogenic $E$. coli infections (UPECS) affect $50 \%$ of women at least once in their life-times. The premises to infections result from the crucial contacts between the bacterial carbohydrates binding proteins type 1 fimbriae (FimH) and PapG which bind uroplakin la glycoprotein and glycolipids, respectively. E. coli type FimH has hair-like appendages on the bacterial cell surface which constitute key virulence factors. They are responsible for the initial adhesion to mucosal surfaces via interaction with multiantennary mannosylated receptors. ${ }^{7}$ Bacterial adhesion to host cells is a preliminary step toward the release of toxic proteins, therefore the design of E. coli FimH antagonists (antiadhesins) has been the target of several efforts from the glycobiology community. ${ }^{7-25}$

Even though several families of potent $\alpha$-D-mannopyranoside-based antiadhesins have been synthesized that included polymers, ${ }^{26-28}$ dendrimers, ${ }^{29-30}$ gold nanoparticles, ${ }^{31}$ and dendrimersomes, ${ }^{32}$ small molecule antagonists still represent the foremost choice of the pharmaceutical industry. Glycomimetics are the most promising candidates for the replacement of naturally occurring complex oligomannosides with C-linked glycosyl derivatives being the preferred options. ${ }^{1,11}$ However, in the case of C-linked mannopyranosides and those possessing hydrophobic/aryl aglycones in particular, there have been very few studies on their precise conformational analyses. ${ }^{33}$ This is particularly important given the propensity of C-mannopyranosides to exist in diverse conformations $\left({ }^{4} \mathrm{C}_{1},{ }^{1} \mathrm{C}_{4},{ }^{2} \mathrm{~S}_{0}\right.$, and $\left.{ }^{0} \mathrm{~S}_{2}\right) .{ }^{34-38}$

This paper describes practical approaches to the syntheses of $C$-allyl $\alpha$-D-mannopyranoside, which is a versatile building block toward E. coli FimH antagonists. Molecular modeling, X-ray crystallography, and binding studies support that $C$-allyl $\alpha$-D-mannopyranosides exist in the required and most stable ${ }^{4} C_{1}$ conformation and that the corresponding $1,1^{\prime}$-biphenyl derivatives, obtained through palladium-catalyzed Heck cross-coupling, represent hydrolytically stable and promising leads as E. coli FimH antagonists.

\section{Results and Discussion}

In conventional drug design, O-linked glycomimetics should be largely avoided due to their propensity to readily hydrolyze in in vivo settings. To avoid this problem, C-linked $\alpha$-D-mannopyranosides attached to alkene chains were investigated. ${ }^{1,11}$ Diversely protected $C$-allyl $\alpha$-D-mannopyranosides are useful intermediates for the synthesis of this important family of glycomimetics. Conventional routes for their syntheses are illustrated in Scheme 1. So far, in its most $\alpha$-stereoselective approach, it was obtained from the known perbenzylated methyl $\alpha$-D-mannopyranoside $\mathbf{1}^{39}$ which under Sakurai reaction ${ }^{39,40}\left(\mathrm{BF}_{3} \cdot \mathrm{OEt}_{2}\right.$, allyltrimethylsilane) provided $\mathbf{2}$ in more than $95 \%$ of its $\alpha$-anomer (Scheme 1). Unfortunately, benzyl protecting groups have some drawbacks for their forthcoming palladium-catalyzed Heck coupling and hydrogenolysis deprotection. ${ }^{11}$ Alternatively, Birch reduction of $\mathbf{2}$ and acetylation affords the more versatile peracetylated analogue $\mathbf{3} \boldsymbol{\alpha}$ in good overall yield, albeit in three consecutive steps. Disappointingly, application of the Sakurai conditions, directly on peracetylated mannose $\mathbf{6} \boldsymbol{\alpha}, \boldsymbol{\beta}$ afforded an intractable mixture of $\mathbf{3 \alpha}$ and $\mathbf{3} \beta .{ }^{41}$ This result prompted us to attempt the reaction on a anomeric mixture of the known perbenzoylated mannopyranose $4 \alpha / 4 \beta .42$ 

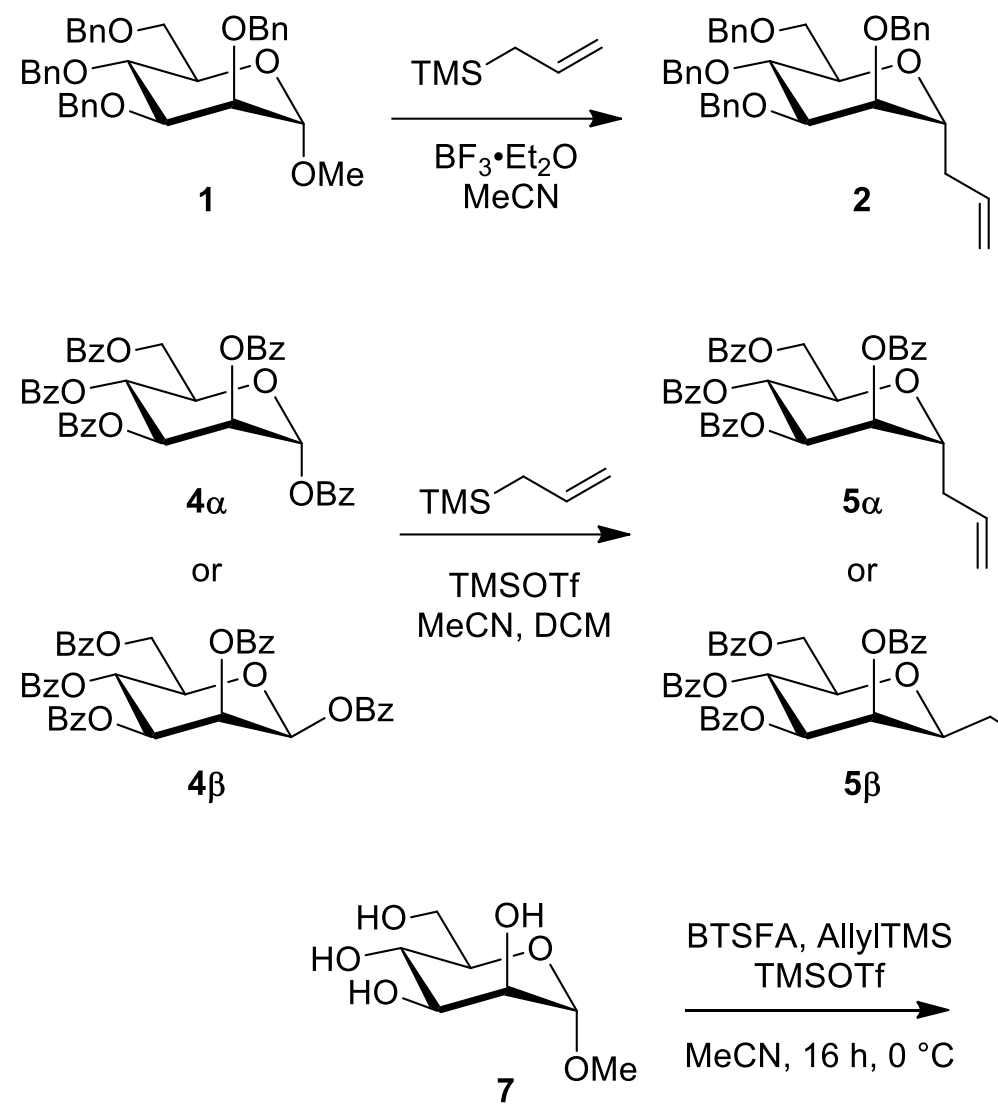

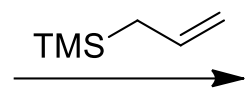

TMSOTf MeCN, DCM

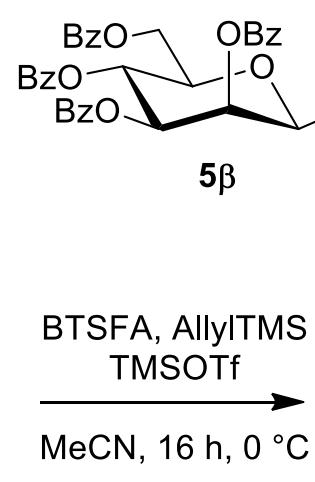

1. $\mathrm{NH}_{3}(\mathrm{I}), \mathrm{Li}$ $\mathrm{THF},-78^{\circ} \mathrm{C}$

2. $\mathrm{Ac}_{2} \mathrm{O}$ Pyridine, 94\%
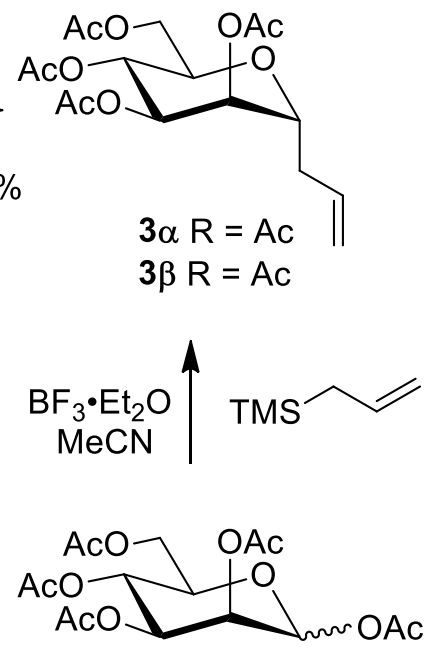

6

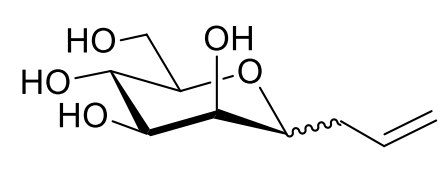

$8 \alpha / 8 \beta$

Scheme 1. Synthesis of $C$-allyl $\alpha$-D-mannopyranosides under Sakurai condition with different protecting groups (see Table 1).

Delightfully, in contrast to the peracetylated analogue $6,{ }^{41}$ the Sakurai products $\mathbf{5} \boldsymbol{\alpha}$ and $\mathbf{5} \boldsymbol{\beta}$ resulting from the perbenzoylated mixture $\mathbf{4} \alpha \mathbf{4} \beta$ were separable, but with reduced $\alpha$-stereoselectivity (7:1) when compared to the perbenzylated derivative $1(15 \alpha: 1 \beta)$. As anticipated, during the course of this transformation, we also observed that $4 \alpha$ reacted faster than its $\beta$-anomer $\mathbf{4} \beta$. Given that $4 \alpha$ and $4 \beta$ were also separable, ${ }^{42}$ we repeated the reaction on each separated isomer: the $4 \alpha$ anomer was completely converted to $5 \alpha / 5 \beta(1.7: 1)$ within $2 \mathrm{~h}$ while the $\mathbf{4} \beta$ anomer provided $\mathbf{5 \alpha / 5 \beta}$ more slowly but with an improved $4: 1$ anomeric stereoselectivity. The fact that the above three conditions gave different anomeric stereoselectivities was not surprising given the individual propensity of the precursors ( $\alpha$ vs $\beta$ ) to react with the Lewis acid competitively.

To simplify access to a suitable and versatile starting material, we attempted the Sakurai reaction directly from the commercially available methyl $\alpha$-D-mannopyranoside 7 using previously described conditions (BTSFA, AllyITMS, TMSOTf, MeCN, $\left.0{ }^{\circ} \mathrm{C}, 16 \mathrm{~h}\right) \cdot{ }^{43,44}$ Although both the yield and the anomeric diastereoselectivity toward unprotected $\mathbf{8} \boldsymbol{\alpha}, \boldsymbol{\beta}$ in one single step from $\mathbf{7}$ was acceptable, the anomeric mixture was not readily separable. The comparative data for the above sets of transformations are illustrated in Table 1 . With this information in hand and for practical reasons, it was decided to pursue our goals using the perbenzoylated precursors $4 \boldsymbol{\alpha}, \boldsymbol{\beta}$. 
Table 1. Synthesis and diastereoselectivity of $C$-allyl $\alpha$-D-mannopyranosides using different methods

$\begin{gathered}\text { Reaction } \\ \text { Conditions }\end{gathered}$
Material

${ }^{a}$ Ratios were obtained from the crude ${ }^{1} \mathrm{H}$ NMR data.

As stated above, ${ }^{33-38}$ there are several papers indicating that $C$-linked $\alpha$-D-mannopyranosides can exist in conformations other than those observed for the corresponding O-linked derivatives, normally seen as ${ }^{4} C_{1}$ conformers. Obviously, changing bond lengths, bond angles, torsion angles, and conformations would have a detrimental effect upon binding of antagonists to $E$. coli FimH. Given the importance of our key precursor, $C$ allyl $\alpha$-D-mannopyranoside $\mathbf{8} \boldsymbol{\alpha}$, we measured the energy levels of its various conformations in the gas phase. The geometry optimizations of the ${ }^{4} C_{1},{ }^{1} C_{4},{ }^{2} S_{0}$ and ${ }^{0} S_{2}$ conformers were performed using density functional theory (DFT) with the hybrid functional B3LYP and 6-31G* basis set. For that purpose, the Firefly ${ }^{45}$ and GaussSum ${ }^{46}$ computer programs were used. Figure 1 clearly showed that the ${ }^{4} C_{1}$ conformer was more stable than its ${ }^{1} \mathrm{C}_{4}$ conformational isomer by at least $8.10 \mathrm{kcal} / \mathrm{mol}$. In addition, the respective skew boats ${ }^{2} \mathrm{~S}_{0}$ and ${ }^{0} \mathrm{~S}_{2}$ conformers were 11.72 and $16.42 \mathrm{kcal} / \mathrm{mol}$, respectively higher than that of the ${ }^{4} \mathrm{C}_{1}$ conformer. These results agreed with the solution phase data obtained from high field ${ }^{1} \mathrm{H}$ NMR $(900 \mathrm{MHz})^{11}$ coupling constants and nOe experiments (see below). Solid phase X-ray data also strongly supported these results. 


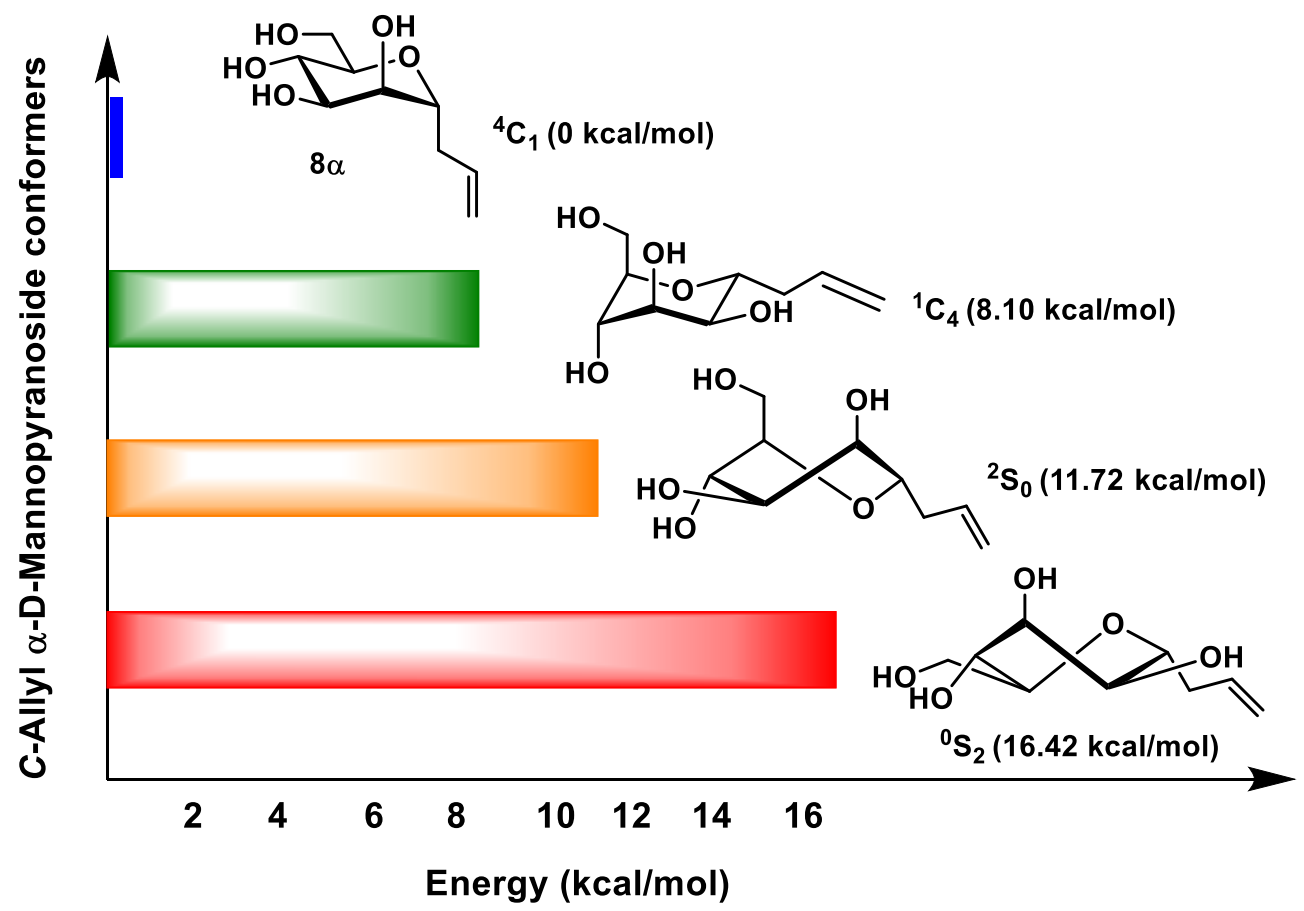

Figure 1. Relative energy level of $C$-allyl $\alpha$-D-mannopyranoside ( $8 \alpha)$ conformers.

NOESY NMR at $600 \mathrm{MHz}$ helped us to demonstrate the solution conformation of $\mathrm{C}$-allyl 2,3,4,6-tetra-Obenzoyl- $\alpha$-D-mannopyranoside ( $5 \alpha)$ (Figure 2). In addition to the expected correlation between $\mathrm{H}_{1}$ and $\mathrm{H}_{1^{\prime} \mathrm{a}}$ and $H_{1^{\prime} b}$, we observed a strong nOe between $H_{1^{\prime} b}$ and $H_{3}$ and $H_{5}$, further confirming that even in the fully protected forms the $\mathrm{C}$-linked mannopyranoside existed in the suitable ${ }^{4} \mathrm{C}_{1}$ conformation. Importantly, the coupling constants for the $\mathrm{H}_{4}$ signal at $\delta_{\mathrm{H}} 6.02\left(\mathrm{dd}, 1 \mathrm{H}, J_{3,4}=J_{4,5}=9 \mathrm{~Hz}, \mathrm{H}-4\right)$ clearly indicated a trans-diaxial relationship between $\mathrm{H}_{4}$ and both $\mathrm{H}_{3}$ and $\mathrm{H}_{5}$. Moreover, a crystal structure of $\mathbf{5} \boldsymbol{\alpha}$ showed it existed in the same ${ }^{4} C_{1}$ conformation. Overall, the data on both fully protected as well as unprotected analogues supported that this family of $\mathrm{C}$-linked mannopyranosides existed in the desired ${ }^{4} C_{1}$ conformation (Figure 3 ).

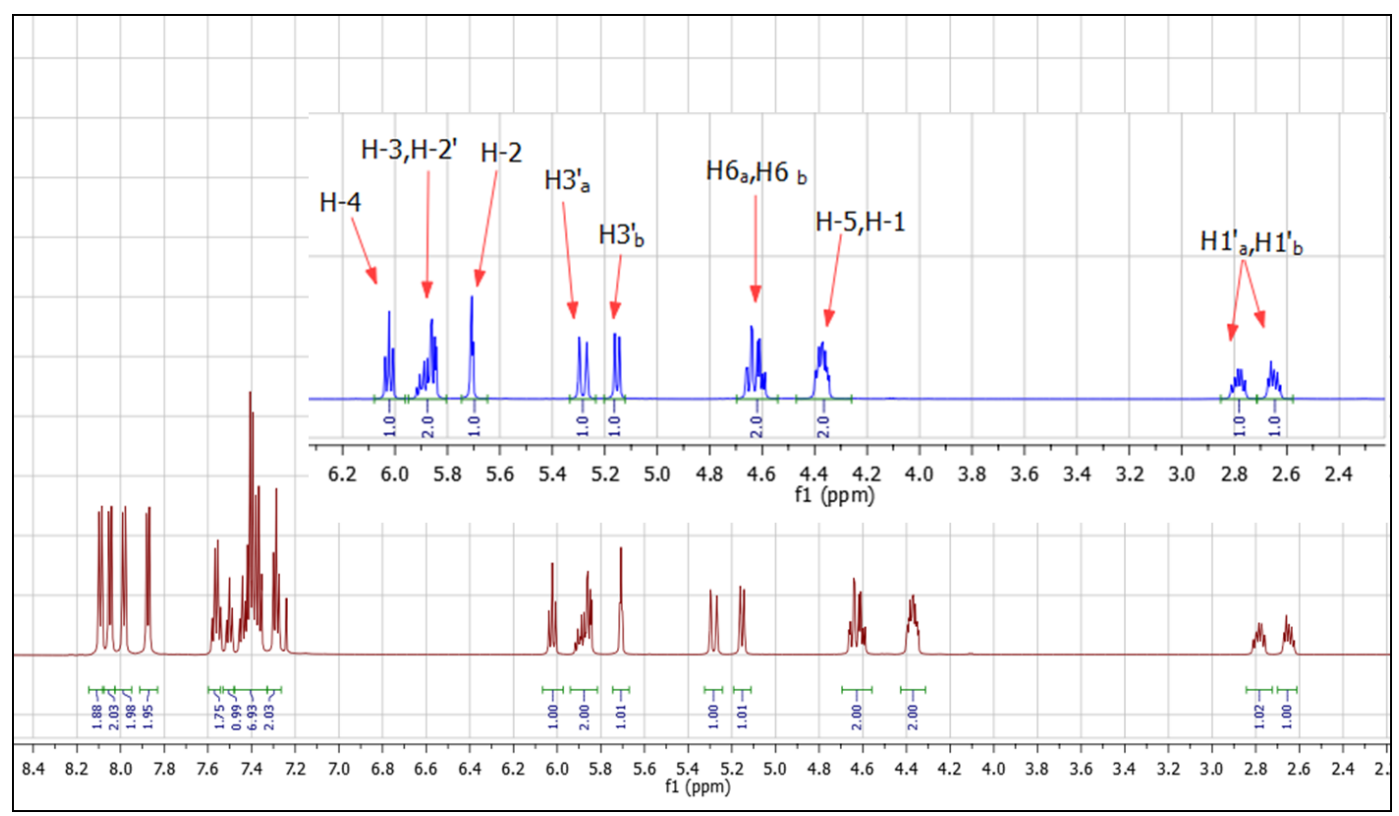

Figure 2. ${ }^{1} \mathrm{H} \mathrm{NMR}\left(\mathrm{CDCl}_{3}, 600 \mathrm{MHz}\right)$ of perbenzoylated $C$-allyl $\boldsymbol{\alpha}$-D-mannopyranoside $\mathbf{5} \boldsymbol{\alpha}$. 

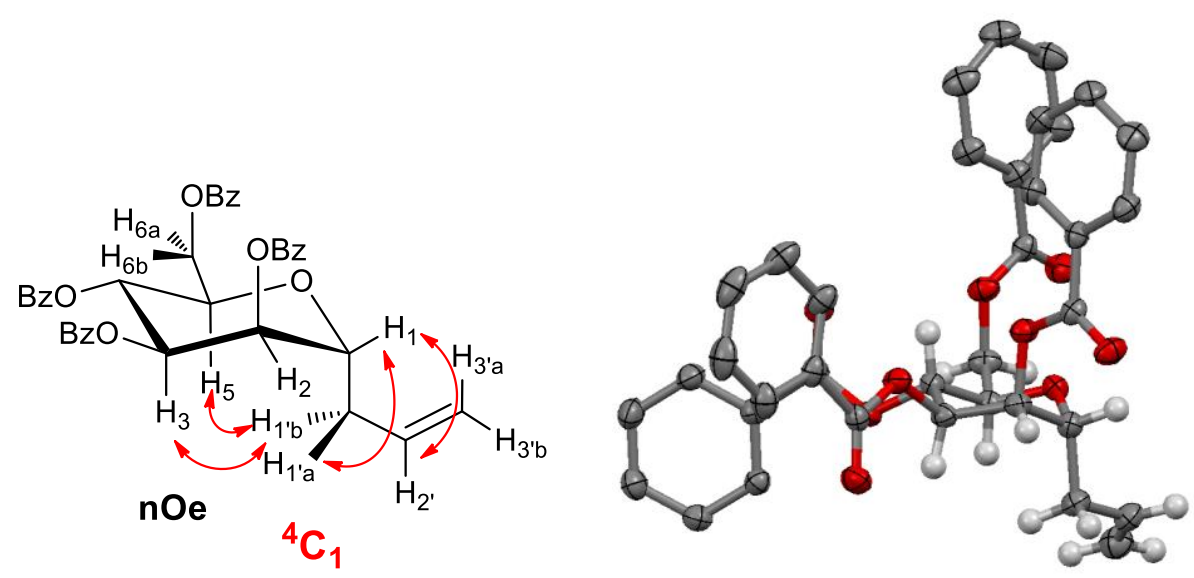

Figure 3. Left panel: conformational studies of $C$-allyl 2,3,4,6-tetra- $O$-benzoyl- $\alpha$-D-mannopyranoside (5 $\boldsymbol{\alpha})$ in solution by nOe ${ }^{1} \mathrm{H} N M R$; right panel: ORTEP diagram for the X-ray structure of $\mathbf{5} \boldsymbol{\alpha}$.

Having secured the accurate ${ }^{4} C_{1}$ conformation of these valuable anomeric precursors ( $4 \boldsymbol{\alpha}$ and $\mathbf{5} \boldsymbol{\alpha}$ ) in the gas phase, solution, and solid-state (X-ray) (Figure 3), we pursued our goals toward potent E. coli FimH antagonists capable of adequately placing hydrophobic pharmacophores within the FimH tyrosine gate (Tyr48/Tyr137). Our hope was to bring anomeric aromatic substituents properly oriented and at proper distances from these two hydrophobic aromatic amino acids for appropriate $\pi$ - $\pi$ stacking (or $\mathrm{CH}-\pi$ stacking), known to greatly improve the binding affinities of FimH ligands. ${ }^{10-15}$ To this end, we opted for an elongation of the aglycone side chain using palladium-catalyzed Heck cross coupling between allylic $\mathbf{5} \boldsymbol{\alpha}$ and aryl iodide such as 4-iodo-1,1'-biphenyl.

Somewhat surprisingly, when allylic $\alpha$-D-mannopyranoside $\mathbf{5} \boldsymbol{\alpha}$ was treated under our optimized conditions (4-iodo-1,1'-biphenyl, $\mathrm{Pd}(\mathrm{OAC})_{2}, \mathrm{TBAB}, \mathrm{NaHCO}_{3}, \mathrm{DMF}, 85^{\circ} \mathrm{C}, 12 \mathrm{~h}$ ), ${ }^{1,11}$ compound 9 was obtained as a major product (93\%) together with traces amount of stereo- and regio-isomers 11 and $\mathbf{1 3}$ (Scheme 2). The mixture of side products (11 and 13) was clearly visible from the ${ }^{1} \mathrm{H}$ NMR spectra of the crude reaction mixture. Their formation has been previously explained when considering the reaction mechanism of the Heck reaction. ${ }^{1}$ After isolation of pure $\mathbf{9}$ (Scheme 2) and 11/13 mixture, they were separately submitted to de-O-benzoylation (1 $\mathrm{M} \mathrm{NH}_{3}, \mathrm{MeOH}$, r.t., $36 \mathrm{~h}$ ) to afford pure 10 (Figure 4) and an intractable mixture of 12/14. These two side products could not be readily purified and fully characterized. Nevertheless, their mixture was submitted to co-crystallization with E. coli FimH together with the major product. Even though we could not obtain X-ray data from the complex of FimH and major product 10, both side products were individually and successfully co-crystallized with the $\mathrm{FimH}^{47}$ in the open and closed tyrosine gate, respectively, thus establishing their exact structures (Figure 5). 


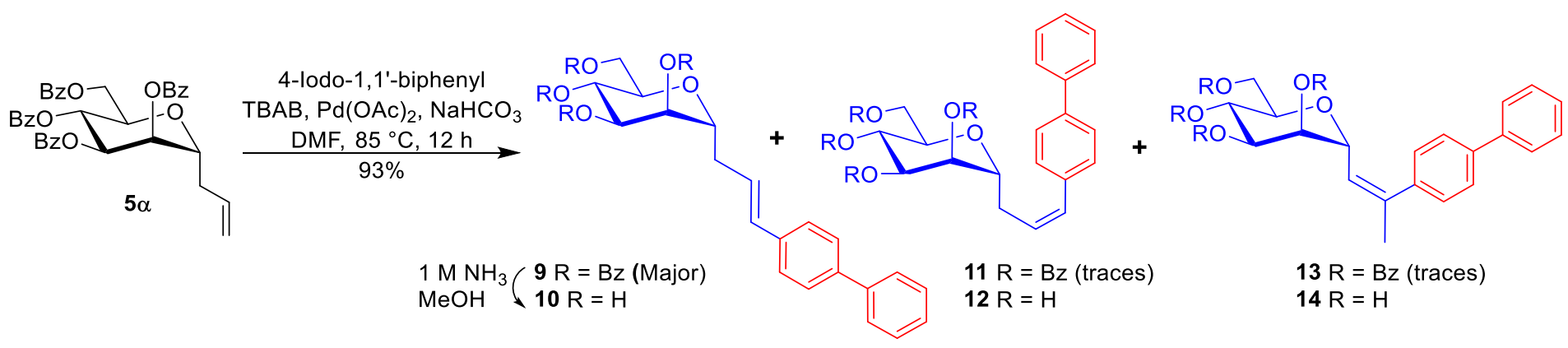

Scheme 2. Heck cross-coupling reactions between $\mathbf{5} \boldsymbol{\alpha}$ and 4-iodo-1,1'-biphenyl that afforded three regio/stereoisomers $\mathbf{9 , 1 1}$ and 13 .

A high field ${ }^{1} \mathrm{H}$ NMR spectrum of deprotected 10 (major product) was fully assigned (Figure 4). The chemical shifts and the coupling constants of the sugar ring protons, together with those of the aglycone were in agreement with derivative 10 being in its expected ${ }^{4} C_{1}$ chair conformation.

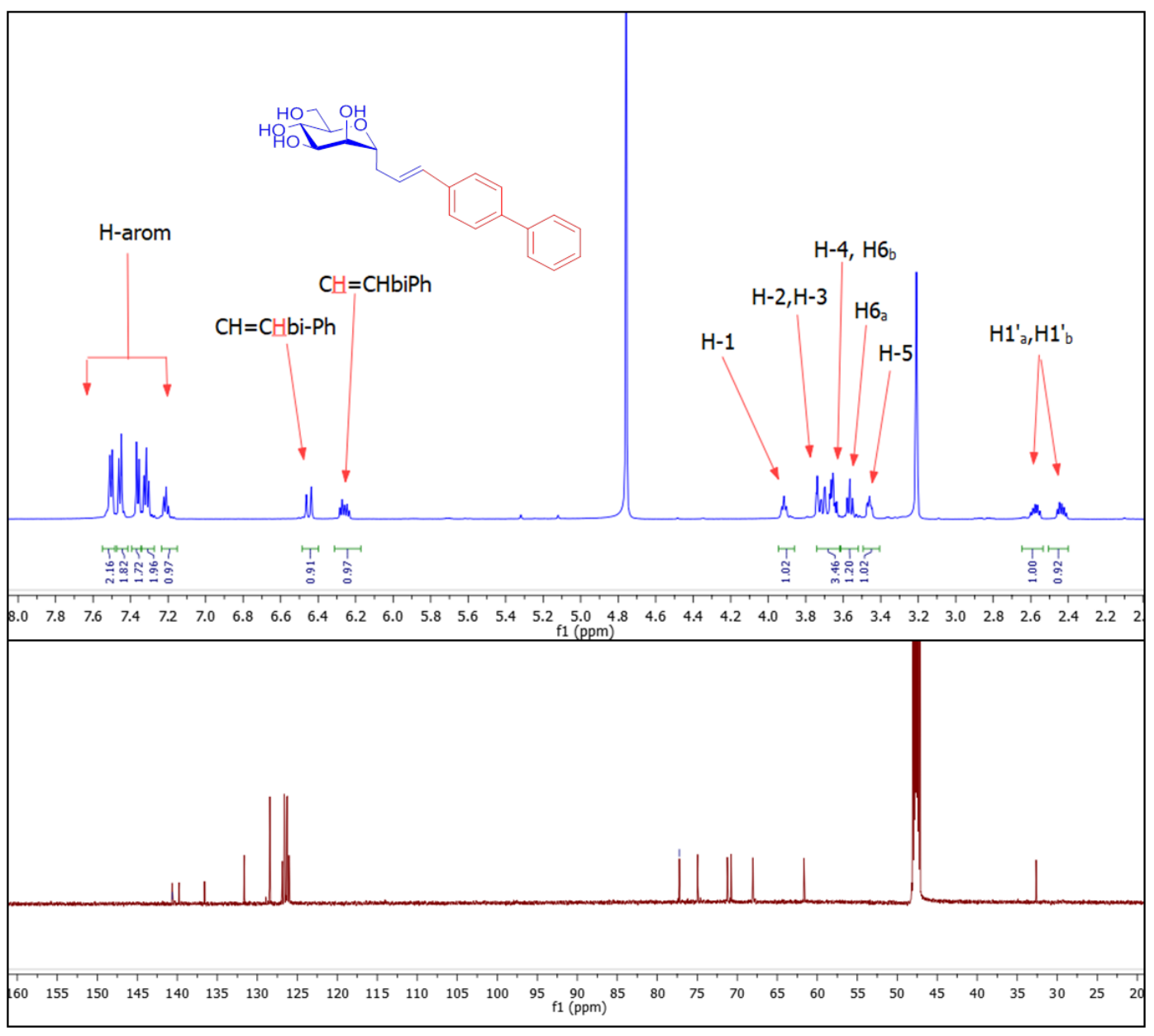

Figure 4. ${ }^{1} \mathrm{H} \mathrm{NMR}(\mathrm{MeOH}, 600 \mathrm{MHz})$ and ${ }^{13} \mathrm{C}$ NMR of compound 10. 


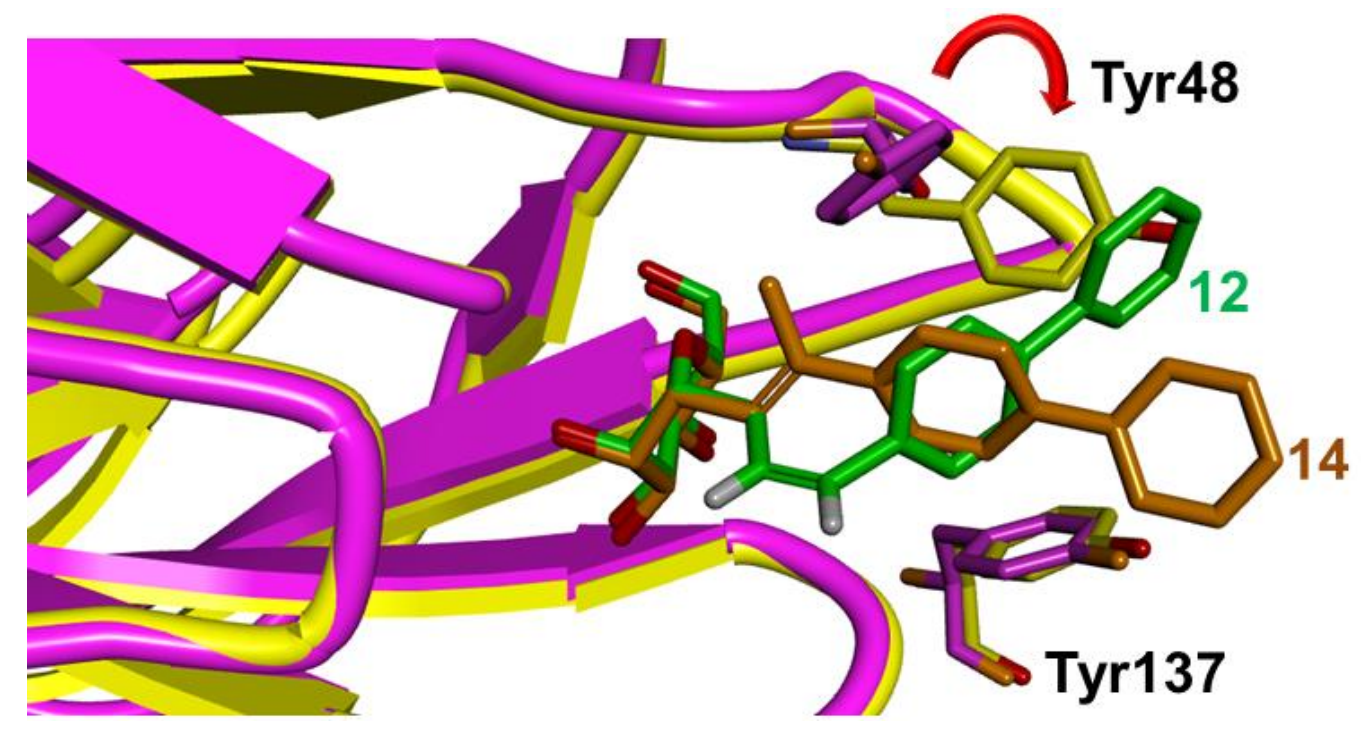

Figure 5. E. coli FimH complexed with side products 12 (green) bound in the open Tyr gate (Tyr48-Tyr137, protein pink, PDB: 5aal) and $\mathbf{1 4}$ (brown) in the closed tyrosine gate (protein yellow, PDB:5aap). ${ }^{47}$

We next undertook affinity measurements between FimH and compound $\mathbf{1 0}$ by surface plasmon resonance (SPR). ${ }^{11}$ Compound 10 , having its second phenyl group in the para-position, was a potent ligand $\left(K_{\mathrm{d}}\right.$ $17 \mathrm{nM}$ ) but it was less potent than the recently identified ortho-substituted analogue $\mathbf{1 5}^{11}$ having an almost 3fold affinity enhancement ( $\left.K_{\mathrm{d}} 6.9 \mathrm{nM}\right)$. As opposed to the two side products 12 and 14 , both compounds could not be co-crystallized with FimH. However, based on previous work, ${ }^{11}$ docking of its lowest energy conformer, obtained through modeling and high field NMR spectra, with the FimH adhesin indicated that the orthosubstituted phenyl ring of $\mathbf{1 5}$ was able to interact with an additional amino acid isoleucine-13 (Ile13), located in the clamp loop, thus opening the route for further lead improvement.
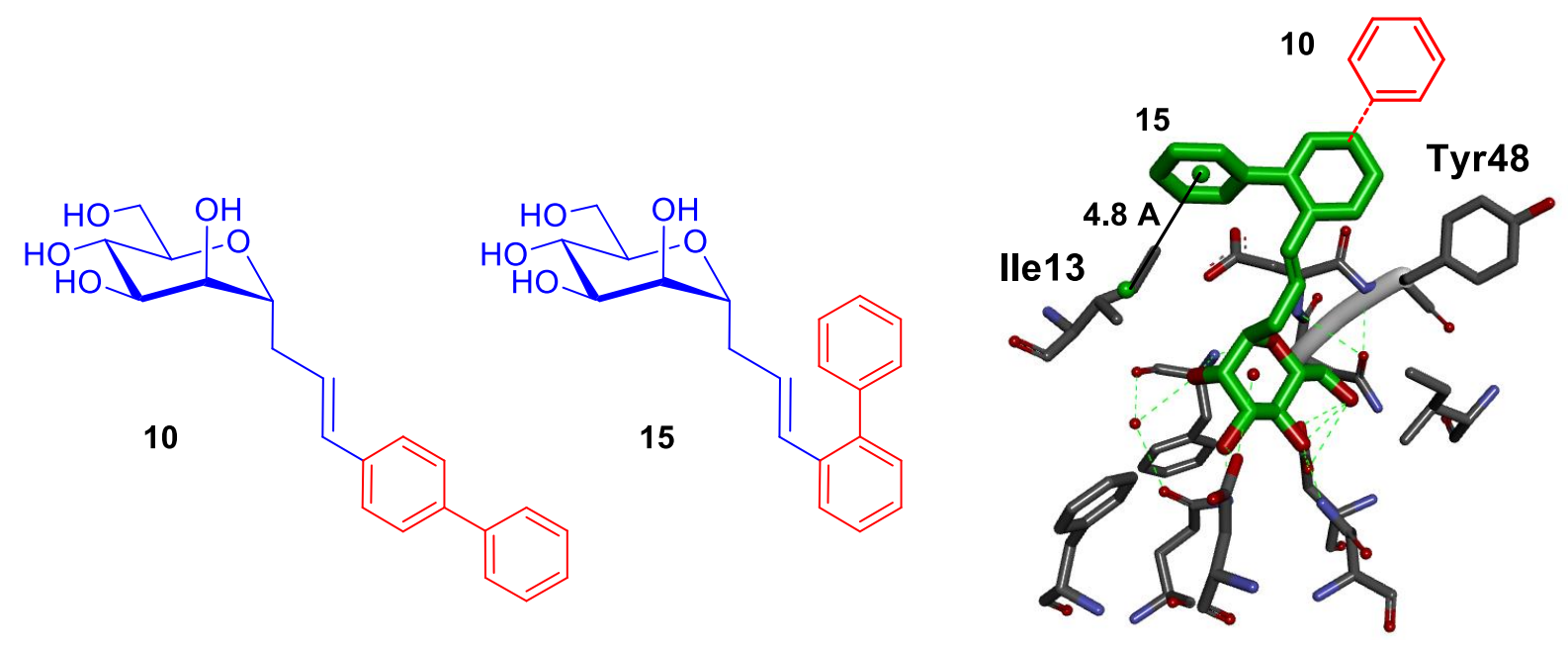

Figure 6. Comparison between para-substituted biphenyl 10 ( $\left.K_{\mathrm{d}} 17 \mathrm{nM}\right)$ and ortho-substituted biphenyl 15 ( $K_{\mathrm{d}}$ $6.9 \mathrm{nM})$; docking of the lowest energy conformer of $\mathbf{1 5}$ in the active site of FimH indicated additional hydrophobic interactions with lle13 (centroid with the ortho-phenyl at $4.8 \AA$ ). 


\section{Conclusions}

Several approaches to an important key intermediate for the synthesis of families of C-linked $\alpha$-Dmannopyranosides have been presented. Although some were more $\alpha$-stereoselective than others, we opted for the use of perbenzoylated precursors for practical reasons. Using optimized Sakurai allylation, good yields of the C-allylated glycosyl derivatives were obtained. We demonstrated that these existed in the required ${ }^{4} C_{1}$ conformation, in the gas phase, solutions, and in the solid-state, as requested for efficient binding interactions with one of the essential E.coli virulence factor FimH. We then explored the formation of the typical, as well as of side products, obtained during the course of our palladium-catalyzed Heck cross-coupling reaction with a key aryl iodide (4-iodo-1,1'-biphenyl). Even though, an X-ray complex between the FimH and the major and expected Heck product could not be acquired, data were obtained from the two minor side products. The findings reveal new opportunities for the design of novel drug candidates against FimH and offer previously unexplored binding interactions within the active site of the protein.

\section{Experimental Section}

General. Reactions were carried out under Nitrogen using commercially available ACS grade solvents which were stored over 4 Á molecular sieves. Solutions in organic solvents were dried over anhydrous $\mathrm{Na}_{2} \mathrm{SO}_{4}$, filtered, and concentrated under reduced pressure. Reagents were obtained from Sigma Aldrich Canada LTD and used without

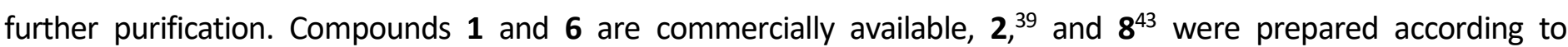
published data and their physical data were in agreement with the proposed structures. Melting points were measured on a Fisher Jones apparatus and are uncorrected. Optical rotations were measured with a JASCO P1010 polarimeter. Reactions were monitored by thin-layer chromatography using silica gel $60 \mathrm{~F}_{254}$ coated plates (E. Merck). ${ }^{1} \mathrm{H}$ and ${ }^{13} \mathrm{C}$ NMR spectra were recorded at 300 or $600 \mathrm{MHz}$ and 75 or $150 \mathrm{MHz}$, respectively, with Varian Gemini 2000 (300 MHz) and Varian Inova $(600 \mathrm{MHz})$ spectrometers. All NMR spectra were measured at $25^{\circ} \mathrm{C}$ in indicated deuterated solvents. Proton and carbon chemical shifts $(\delta)$ are reported in ppm relative to the chemical shift of residual $\mathrm{CHCl}_{3}$, which was set at $7.28 \mathrm{ppm}\left({ }^{1} \mathrm{H}\right)$ and $77.16 \mathrm{ppm}\left({ }^{13} \mathrm{C}\right)$. Coupling constants $(J)$ are reported in Hertz $(\mathrm{Hz})$, and the following abbreviations are used for peak multiplicities: singlet (s), doublet (d), doublet of doublets $(\mathrm{dd})$, doublet of doublet with equal coupling constants $\left(t_{a p}\right)$, triplet $(t)$, multiplet $(m)$. Assignments were made using COSY (COrrelated SpectroscopY) and HSQC (Heteronuclear Single Quantum Coherence) experiments. High-resolution mass spectra (HRMS) were measured with a LC-MS-TOF (Liquid Chromatography Mass Spectrometry Time of Flight) instrument (Agilent Technologies) in positive and/or negative electrospray mode by the analytical platform of UQAM. Compounds 11-14 were only obtained in trace amounts that could not be fully characterized except through the X-ray data of their unprotected FimH complexes (12, 14) (Figure 5). The $X$-ray data were deposited as PDB accession no. 5AAL and 5AAP, respectively.

1,2,3,4,6-Penta-O-benzoyl-D-mannopyranose $(\mathbf{4} \boldsymbol{\alpha}, \mathbf{4 \beta}) .^{42} \mathrm{D}$-Mannose $(3.00 \mathrm{~g}, 16.7 \mathrm{mmol})$ was dissolved in pyridine to which was added benzoyl chloride $(1: 5 \mathrm{v} / \mathrm{v})$. After stirring for $16 \mathrm{~h}$ at room temperature, the excess benzoyl chloride was quenched with methanol and the reaction mixture was concentrated under vacuum. The crude residue was dissolved in dichloromethane, washed successively with $\mathrm{NaHCO}_{3}$, brine, and dried $\left(\mathrm{Na}_{2} \mathrm{SO}_{4}\right)$. A crude mixture of $4 \alpha / 4 \beta(10.6 \mathrm{~g}, 14.27 \mathrm{mmol})$ was obtained. The anomeric ratio $\left({ }^{1} \mathrm{H} N M R\right)$ of the two anomers was $(75 \alpha: 25 \beta)$ similar to that previously obtained from the literature. ${ }^{42}$ The residue was purified by 
flash silica gel column chromatography using (PhMe/EtOAc, 9.8:0.2) to provide $4 \alpha(40 \%), R_{f} \alpha=0.33$ and $4 \beta$ $(48 \%), R_{f} \beta=0.21$. Physical data agreed with those present in the literature. ${ }^{42}$

2,3,4,6-(Tetra-O-benzoyl- $\alpha$-D-mannopyranosyl)-1-propene (5 $\boldsymbol{\alpha}$ ). To an ice-cold solution of $1,2,3,4,6$-tetra-Obenzoyl- $\alpha$-D-mannopyranose (4) (3.46 g, $4.94 \mathrm{mmol}$ ) in dry acetonitrile (13 mL) and $\mathrm{CH}_{2} \mathrm{Cl}_{2}(7 \mathrm{~mL})$ was added allylTMS (1.17 mL, 1.5 equiv) followed by $\mathrm{BF}_{3} \cdot \mathrm{Et}_{2} \mathrm{O}(1.08 \mathrm{~mL}, 1.9$ equiv) and TMSOTf (0.98. $\mathrm{mL}, 1.1$ equiv) added dropwise during $20 \mathrm{~min}$. The reaction mixture was heated at $50{ }^{\circ} \mathrm{C}$ under $\mathrm{N}_{2}$ for $48 \mathrm{~h}$. The course of the reaction was monitored by TLC. The solution was evaporated under reduced pressure then diluted with dichloromethane which was washed with $\mathrm{NaHCO}_{3}$. The organic layer was separated and dried $\left(\mathrm{Na}_{2} \mathrm{SO}_{4}\right)$, filtered, and concentrated to provide an $\alpha / \beta$ anomeric mixture in 7:1 ratio: $R_{f} \alpha=0.36, R_{f} \beta=0.31$. Purification and separation of $\alpha$ anomer was done by silica gel column chromatography (Hex/EtOAc, 4:1) to afford the title compound $5 \alpha$ as a colorless powder $(1.2 \mathrm{~g}, 40 \%): \mathrm{mp} 112-114{ }^{\circ} \mathrm{C}\left(\mathrm{EtOH} / \mathrm{Et}_{2} \mathrm{O}\right) ;[\alpha]_{20} \mathrm{D}=-62.6\left(\mathrm{c}=0.18, \mathrm{CHCl}_{3}\right)$. ${ }^{1} \mathrm{H}$ NMR $\left(600 \mathrm{MHz}, \mathrm{CDCl}_{3}\right): \delta_{\mathrm{H}} 7.24-8.21\left(\mathrm{~m}, 2 \mathrm{H}, \mathrm{H}\right.$-arom), $6.02\left(\mathrm{t}, 1 \mathrm{H}, J_{3,4}=J_{4,5}=9.0, \mathrm{H}-4\right), 5.91-5.84(\mathrm{~m}, 2 \mathrm{H}$, $\underline{\mathrm{CH}}=\mathrm{CH}_{2}$ and $\mathrm{H}-3$ ), $5.71\left(\mathrm{dd}, 1 \mathrm{H}, J_{1,2}=J_{2,3}=2.9, \mathrm{H}-2\right), 5.28\left(\mathrm{dd}, 1 \mathrm{H}, J_{\text {trans }}=17.1, J_{\mathrm{ge}}<1.0, \mathrm{CH}=\mathrm{CH} H\right), 5.15(\mathrm{dd} 1 \mathrm{H}$, $\left.J_{\text {cis }}=10.2, J_{\text {gem }}<1.0, \mathrm{CH}=\mathrm{CHH}\right), 4.66\left(\mathrm{dd}, 1 \mathrm{H}, J_{6 \mathrm{a}, 6 \mathrm{~b}}=12.0, J_{5,6 \mathrm{a}}=5.4, \mathrm{H}-6 \mathrm{a}\right), 4.60\left(\mathrm{dd}, 1 \mathrm{H}, J_{6 a, 6 b}=12.0, J_{5,6 b}=2.9\right.$, $\mathrm{H}-6 \mathrm{~b}), 4.45-4.25(\mathrm{~m}, 2 \mathrm{H}, \mathrm{H}-1, \mathrm{H}-5), 2.77$ (ddd, $\left.1 \mathrm{H}, J_{1^{\prime} \mathrm{a}, 1^{\prime} \mathrm{b}}=8.5, J_{1^{\prime} \mathrm{a}, 2^{\prime}}=7.9, J_{1^{\prime} \mathrm{a}, 1}=7.2\right), 2.65$ (ddd, 1H, $J_{1^{\prime} b, 1^{\prime} \mathrm{a}}=7.7$, $\left.J_{1^{\prime} b, 2}=7.2, J_{1^{\prime} b, 1}=6.4\right) ;{ }^{13} \mathrm{C} \mathrm{NMR}\left(\mathrm{CDCl}_{3}\right): \delta_{\mathrm{C}} 166.6,165.6,165.5,165.4$ (4 CO), $133.4\left(\mathrm{C}-2^{\prime}\right), 133.3,133.3,133.0$ (C arom-q), 129.7, 129.5, 128.9, 128.1, (C arom), 118.4 (C-3'), 74.6 (C-1), 71.2 (C-5), 70.6 (C-4), 69.9 (C-3), 67.4 (C2), $62.8(\mathrm{C}-6), 33.5$ (C-1'). ESI+ ${ }^{+}$HRMS: $[\mathrm{M}+\mathrm{H}]^{+}$calcd for $\mathrm{C}_{37} \mathrm{H}_{32} \mathrm{O}_{9}+\mathrm{H}^{+}$: 621.2119, found, 621.2143.

(E)-4-[3-(2,3,4,6-Tetra-O-benzoyl- $\alpha$-D-mannopyranosyl)prop-1-en-1-yl]-1,1'-biphenyl (9). To a solution of mannoside $5 \alpha(50 \mathrm{mg}, 0.08 \mathrm{mmol}$ ) in DMF were added 4-iodo-1,1'-biphenyl (45 mg, 2 equiv), 15\% palladium(II) acetate, tetrabutylammonium bromide (25 mg, 1 equiv), and sodium bicarbonate (20 mg, 3 equiv). The reaction mixture was heated at $85{ }^{\circ} \mathrm{C}$ under $\mathrm{N}_{2}$ for $24 \mathrm{~h}$. The solution was concentrated under reduced pressure and the residue was purified by flash column chromatography using silica gel column chromatography (PhMe/EtOAc, 3:1) to afford the title compound 9 as a colorless oil $(57.2 \mathrm{mg}, 93 \%)$. $[\alpha]_{20} \mathrm{D}=-$ 11.05 ( $\left.\mathrm{c}=0.7, \mathrm{CHCl}_{3}\right) .{ }^{1} \mathrm{H} \mathrm{NMR}\left(600 \mathrm{MHz}, \mathrm{CDCl}_{3}\right) \delta_{\mathrm{H}} 8.10-7.25\left(\mathrm{~m}, 29 \mathrm{H}, \mathrm{H}\right.$-arom), $6.65\left(\mathrm{~d}, 1 \mathrm{H}, J_{2^{\prime}, 3^{\prime}}=15.8\right.$, $\mathrm{CH}=\mathrm{C} \underline{\mathrm{H}}-\mathrm{biPh}), 6.36-6.23$ (m, $1 \mathrm{H}, \mathrm{C} \underline{\mathrm{H}}=\mathrm{CH}-\mathrm{biPh}), 5.96$ (dd, $\left.1 \mathrm{H}, J_{3,4}=8.9, J_{4,5}=2.0, \mathrm{H}-4\right), 5.91$ (dd, $1 \mathrm{H}, J_{2,3}=3.0, J_{3,4}$ $=8.9, \mathrm{H}-3$ ), $5.20\left(\mathrm{dd}, 1 \mathrm{H}, J_{1,2}=1.5, J_{2,3}=3.3, \mathrm{H}-2\right), 4.58\left(\mathrm{dd}, 1 \mathrm{H}, J_{6 \mathrm{a}, 6 \mathrm{~b}}=12.0, J_{5,6 \mathrm{a}}=6.1, \mathrm{H}-6 \mathrm{a}\right), 4.50$ (dd, $1 \mathrm{H}, J_{6 \mathrm{a}, 6 \mathrm{~b}}$ $\left.=12.1, J_{5,6 b}=2.8, \mathrm{H}-6 \mathrm{~b}\right), 4.57-4.33(\mathrm{~m}, 2 \mathrm{H}, \mathrm{H}-5, \mathrm{H}-1), 3.10-2.90\left(\mathrm{~m}, 1 \mathrm{H}, \mathrm{H} 1^{\prime} \mathrm{a}\right), 2.90-2.70\left(\mathrm{~m}, 1 \mathrm{H}, \mathrm{H} 1^{\prime} \mathrm{b}\right) ;{ }^{13} \mathrm{C} \mathrm{NMR}$ $\left(\mathrm{CDCl}_{3}\right): \delta_{\mathrm{C}} 171.7,166.3,165.6,165.5$ (4CO), 140.8, 140.0, 136.9 (C arom-q), 136.0, 133.7, 133.2, 129.9, 128.5, 126.9, (C arom, C-3'), 124.2 (C-2'), 74.6 (C-1), 71.3 (C-5), 70.8 (C-4), 69.8 (C-3), 67.4 (C-2), 63.1 (C-6), 33.0 (C$\left.1^{\prime}\right)$. ESI ${ }^{+}-\mathrm{HRMS}:[\mathrm{M}+\mathrm{H}]^{+}$calcd for $\mathrm{C}_{49} \mathrm{H}_{40} \mathrm{O}_{9}+\mathrm{H}^{+}:$773.2745; found, 773.2745 .

(E)-4-[3-( $\alpha$-D-Mannopyranosyl)prop-1-en-1-yl]-1,1'-biphenyl (10). Compound 9 (50 mg, 0.064 mmol) was deprotected by treatment with $1 \mathrm{M}$ ammonia in methanol $(0.1 \mathrm{M})$ at room temperature for $36 \mathrm{~h}$. Removal of solvent under vacuum afforded the crude residue which was purified by semi-preparative HPLC (A: $\mathrm{H}_{2} \mathrm{O}+0.1 \%$ trifluoroacetic acid, B: MeCN + 0.1\% trifluoroacetic acid, $5 \mathrm{~mL} / \mathrm{min}$ ) to afford the title compound 10 (24.9 $\mathrm{mg}$, 96\%). $[\alpha]^{20}{ }_{\mathrm{D}}=30.2(c=1.0, \mathrm{MeOH}) .{ }^{1} \mathrm{H} \mathrm{NMR}\left(600 \mathrm{MHz}, \mathrm{CD}_{3} \mathrm{OD}\right): \delta_{\mathrm{H}} 7.50\left(\mathrm{~d}, 2 \mathrm{H}, \mathrm{J}_{\mathrm{HH}}=7.5, \mathrm{H}\right.$-arom), $7.45(\mathrm{t}, 2 \mathrm{H}$, $J_{H H}=8.2, \mathrm{H}$-arom), $7.36\left(\mathrm{~d}, 2 \mathrm{H}, J_{\mathrm{HH}}=8.2, \mathrm{H}\right.$-arom), 7.31 (dd, $2 \mathrm{H}, J_{\mathrm{HH}}=8.0,15.8, \mathrm{H}$-arom), 7.20 (dd, $1 \mathrm{H}, J_{\mathrm{HH}}=8.1$, 15.4, H-arom), $6.45\left(\mathrm{~d}, 1 \mathrm{H}, J_{2^{\prime}, 3^{\prime}}=15.6, \mathrm{CH}=\mathrm{C} \underline{H} \mathrm{Ph}\right), 6.29-6.22(\mathrm{~m}, 1 \mathrm{H}, \mathrm{C} \underline{H}=\mathrm{CHPh}), 3.93-3.90(\mathrm{~m}, 1 \mathrm{H}, \mathrm{H}-1), 3.74$ (dd, $\left.1 \mathrm{H} J_{1,2}=J_{2,3}=2.8, \mathrm{H}-2\right), 3.71\left(\mathrm{dd}, 1 \mathrm{H}, J_{2,3}=2.6, J_{3,4}=11.7, \mathrm{H}-3\right), 3.68-3.62(\mathrm{~m}, 2 \mathrm{H}, \mathrm{H}-4, \mathrm{H}-6 \mathrm{~b}), 3.56(\mathrm{dd}, 1 \mathrm{H}$, $\left.J_{5,6 a}=9.0, J_{6 a, 6 b}=8.4, \mathrm{H}-6 \mathrm{a}\right), 3.48-3.41(\mathrm{~m}, 1 \mathrm{H}, \mathrm{H}-5), 2.67-2.51\left(\mathrm{~m}, 1 \mathrm{H}, \mathrm{Ha} \mathrm{a}^{\prime}\right), 2.49-2.40(\mathrm{~m}, 1 \mathrm{H}, \mathrm{Ha}) .{ }^{13} \mathrm{C} \mathrm{NMR}(600$ $\mathrm{MHz}, \mathrm{CD}_{3} \mathrm{OD}$ ): $\delta_{\mathrm{C}} 140.6,140.1,136.9$ (C arom-q), 131.6 (C-3'), 128.4, 126.8, 126.6, 126.3, 126.2, 126.0 (C arom, C-2'), 77.2 (C-1), 74.9 (C-5), 71.2 (C-4), 70.7 (C-3), 68.0 (C-2), 61.6 (C-6), 32.5 (C-1'). ESI ${ }^{+}-\mathrm{HRMS}_{\mathrm{R}}\left[\mathrm{M}+\mathrm{NH}_{4}\right]^{+} \mathrm{calcd}$ for $\mathrm{C}_{21} \mathrm{H}_{28} \mathrm{NO}_{5}, 374.1962$; found, 374.1960. 
X-Ray crystal-structure of $\mathbf{5} \boldsymbol{\alpha}$ and refinement data: formula, $\left(\mathrm{C}_{37} \mathrm{H}_{32} \mathrm{O}_{9}\right)$, orthorhombic, space group $\mathrm{P} 212121$, a

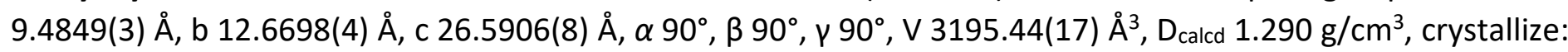
$0.3 \times 0.28 \times 0.18 \mathrm{~mm}^{3}$. Index ranges-12 $\leq \mathrm{h} \leq 12,-16 \leq \mathrm{k} \leq 16,-34 \leq \mathrm{I} \leq 34$. Crystallographic data for the structure reported in this paper has been deposited at the Cambridge Crystallographic Data Centre (CCDC) with deposition no: 1560370 for $\mathrm{C}_{37} \mathrm{H}_{32} \mathrm{O}_{9}$. Supplementary data can be obtained free of charge from CCDC, 12 Union Road, Cambridge CB2 1EZ, UK (fax: (+44)1223-336-033; e-mail: deposit@ccdc.cam.ac.uk, website http://www.ccdc.cam.ac.uk).

\section{Acknowledgements}

This work was supported by grants from the Natural Science and Engineering Research Council of Canada (NSERC) to R. Roy including a Canadian Research Chair and the Fonds du Québec - Nature et Technologies to R.R.

\section{References}

1. Mousavifar, L.; Touaibia, M.; Roy, R. Acc. Chem. Res. 2018, 51, 2937

https://doi.org/10.1021/acs.accounts.8b00397

2. Terlizzi, M. E.; Gribaudo, G.; Maffei, M. E. Front. Microbiol. 2017, 8, 1. https://doi.org/10.3389/fmicb.2017.01566

3. Mousavifar, L.; Roy, R. Trends Med. Chem. 2018, 1, 1. https://doi.org/10.15761/FDCCR.1000115

4. Meylan, S.; Andrews, I. W.; Collins, J. J. Cell 2018, 172, 1228. https://doi.org/10.1016/j.cell.2018.01.037

5. Simões, N. G.; Bettencourt, A. F.; Monge, N.; Ribeiro, I. A. C. Mini-Rev. Med. Chem. 2017, 17, 1364. https://doi.org/10.2174/1389557516666160907151454

6. Palmela, C.; Chevarin, C.; Xu, Z.; Torres, J.; Sevrin, G.; Hirten, R.; Barnich, N.; Ng, S. C.; Colombel, J. F. Gut 2018, 67, 574.

https://doi.org/10.1136/gutjnl-2017-314903

7. Bouckaert, J.; Berglund, J.; Schembri, M.; De Genst, E.; Cools, L.; Wuhrer, M.; Hung, C. S.; Pinkner, J.; Slättegård, R.; Zavialov, A.; Choudhury, D.; Langermann, S.; Hultgren, S. J.; Wyns, L.; Klemm, P.; Oscarson, S.; Knight, S. D.; De Greve, H. Mol. Microbiol. 2005, 55, 441.

https://doi.org/10.1111/i.1365-2958.2004.04415.x

8. Dorta, D. M.; Sivignon, A.; Chalopin, T.; Dumych, T. A.; Roos, G.; Bilyy, R. O.; Deniaud, D.; Krammer, E.-M.; de Ruyck, J.; Lensink, M. F.; Bouckaert, J.; Barnich, N.; Gouin, S. G. ChemBioChem 2016, 17, 936.

https://doi.org/10.1002/cbic.201600018

9. Sharon, N. FEBS Lett. 1987, 217, 145.

https://doi.org/10.1016/0014-5793(87)80654-3

10. Firon, N.; Ashkenazi, S.; Mirelman, D.; Ofek, I.; Sharon, N. Infect. Immun. 1987, 55, 472.

11. Touaibia, M.; Krammer, E.-M.; Shiao, T. C.; Yamakawa, N.; Wang, Q.; Glinschert, A.; Papadopoulos, A.; Mousavifar, L.; Maes, E.; Oscarson, S.; Vergoten, G.; Lensink, M.; Roy, R.; Bouckaert, J. Molecules 2017, 22, 1. 
https://doi.org/10.3390/molecules22071101

12. Wellens, A.; Lahmann, M.; Touaibia, M.; Vaucher, J.; Oscarson, S.; Roy, R.; Remaut, H.; Bouckaert, J. Biochemistry 2012, 51, 4790.

https://doi.org/10.1021/bi300251r

13. Roos, G.; Wellens, A.; Touaibia, M.; Yamakawa, N.; Geerlings, P.; Roy, R.; Wyns, L.; Bouckaert, J. ACS Med. Chem. Lett. 2013, 4, 1085.

https://doi.org/10.1021/ml400269v

14. Vanwetswinkel, S.; Volkov, A. N.; Sterckx, Y. G.; Garcia-Pino, A.; Buts, L.; Vranken, W. F.; Bouckaert, J.; Roy, R.; Wyns, L.; van Nuland, N. A. J. Med. Chem. 2014, 57, 1416.

https://doi.org/10.1021/jm401666c

15. Touaibia, M.; Wellens, A.; Shiao, T. C.; Wang, Q.; Sirois, S.; Bouckaert, J.; Roy, R. ChemMedChem 2007, 2, 1190.

https://doi.org/10.1002/cmdc.200700063

16. Gouin, S. G.; Roos, G.; Bouckaert, J. Top. Med. Chem. 2014, 12, 123.

https://doi.org/10.1007/7355 201452

17. Chalopin, T.; Brissonnet, Y.; Sivignon, A.; Deniaud, D.; Cremet, L.; Barnich, N.; Bouckaert, J.; Gouin, S. G. Org. Biomol. Chem. 2015, 13, 11369.

https://doi.org/10.1039/C5OB01581B

18. Schwardt, O.; Rabbani, S.; Hartmann, M.; Abgottspon, D.; Wittwer, M.; Kleeb, S.; Zalewski, A.; Smiesko, M.; Cutting, B.; Ernst, B. Bioorg. Med. Chem. 2011, 19, 6454.

https://doi.org/10.1016/j.bmc.2011.08.057

19. Jiang, X.; Abgottspon, D.; Kleeb, S.; Rabbani, S.; Scharenberg, M.; Wittwer, M.; Haug, M.; Schwardt, O.; Ernst, B. J. Med. Chem. 2012, 55, 4700.

https://doi.org/10.1021/jm300192x

20. Kleeb, S.; Jiang, X.; Frei, P.; Sigl, A.; Bezencon, J.; Bamberger, K.; Schwardt, O.; Ernst, B. J. Med. Chem. 2016, $59,3163$.

https://doi.org/10.1021/acs.jmedchem.5b01923

21. Fiege, B.; Rabbani, S.; Preston, R. C.; Jakob, R. P.; Zihlmann, P.; Schwardt, O.; Jiang, X.; Maier, T.; Ernst, B. ChemBioChem 2015, 16, 1235.

https://doi.org/10.1002/cbic.201402714

22. Pang, L.; Kleeb, S.; Lemme, K.; Rabbani, S.; Scharenberg, M.; Zalewski, A.; Schadler, F.; Schwardt, O.; Ernst, B. ChemMedChem 2012, 7, 1404. https://doi.org/10.1002/cmdc.201200125

23. Scharenberg, M.; Schwardt, O.; Rabbani, S.; Ernst, B. J. Med. Chem. 2012, 55, 9810.

https://doi.org/10.1021/jm3010338

24. Han, Z.; Pinkner, J. S.; Ford, B.; Chorell, E.; Crowley, J. M.; Cusumano, C. K.; Campbell, S.; Henderson, J. P.; Hultgren, S. J.; Janetka, J. W. J. Med. Chem. 2012, 55, 3945.

https://doi.org/10.1021/jm300165m

25. Mydock-McGrane, L.; Cusumano, Z.; Han, Z.; Binkley, J.; Kostakioti, M.; Hannan, T.; Pinkner, J. S.; Klein, R.; Kalas, V.; Crowley, J.; Rath, N. P.; Hultgren, S. J.; Janetka, J. W. J. Med. Chem. 2016, 59, 9390. https://doi.org/10.1021/acs.jmedchem.6b00948

26. Roy, R. Trends Glycosci. Glycotechnol. 1996, 8, 79.

https://doi.org/10.4052/tigg.8.79 
27. Xue, C.; Velayudham, S.; Johnson, S.; Saha, R.; Smith, A.; Brewer, W.; Murthy, P.; Bagley, S. T.; Liu, H. Chem. Eur. J. 2009, 15, 2289.

https://doi.org/10.1002/chem.200801875

28. Barth, K. A.; Coullerez, G.; Nilsson, L. M.; Castelli, R.; Seeberger, P. H.; Vogel, V.; Textor, M. Adv. Funct. Mater. 2008, 18, 1459.

https://doi.org/10.1002/adfm.200701246

29. Nagahori, N.; Lee, R. T.; Nishimura, S.-I.; Pagé, D.; Roy, R.; Lee, Y. C. ChemBioChem 2002, 3, 836. https://doi.org/10.1002/1439-7633(20020902)3:9<836::AID-CBIC836>3.0.CO;2-2

30. Chabre, Y. M.; Roy, R. Adv. Carbohydr. Chem. Biochem. 2010, 63, 165. https://doi.org/10.1016/S0065-2318(10)63006-5

31. Tseng, Y.-T.; Chang, H.-T.; Chen, C.-T.; Chen, C.-H.; Huang, C.-C. Biosens. Bioelectron. 2011, $27,95$. https://doi.org/10.1016/j.bios.2011.06.021

32. Zhang, S.; Moussodia, R. O.; Murzeau, C.; Sun, H. J.; Klein, M. L.; Vértesy, S.; André, S.; Roy, R.; Gabius, H. J.; Percec, V. Angew. Chem. Int. Ed. 2015, 54, 4036. https://doi.org/10.1002/anie.201410882

33. Choumane, M.; Banchet, A.; Probst, N.; Gérard, S.; Plé, K.; Haudrechy, A. C. R. Chim. 2011, $14,235$. https://doi.org/10.1016/j.crci.2010.05.015

34. Schwardt, O.; Rabbani, S.; Hartmann, M.; Abgottspon, D.; Wittwer, M.; Kleeb, S.; Zalewski, A.; Smieško, M.; Cutting, B.; Ernst, B. Bioorg. Med. Chem. 2011, 19, 6454. https://doi.org/10.1016/j.bmc.2011.08.057

35. George, T. G.; Szolcsányi, P.; Koenig, S. G.; Paterson, D. E.; Isshiki, Y.; Vasella, A. Helv. Chim. Acta 2004, 87, 1287.

https://doi.org/10.1002/hlca.200490118

36. Skrydstrup, T.; Jarreton, O.; Mazéas, D.; Urban, D.; Beau, J.-M. Chem. -Eur. J. 1998, 4, 655. https://doi.org/10.1002/(SICI)1521-3765(19980416)4:4<655::AID-CHEM655>3.0.CO;2-4

37. Jiménez-Barbero, J.; Espinosa, J. F.; Asensio, J. L.; Cañada, F. J.; Poveda, A. Adv. Carbohydr. Chem. Biochem. 2001, 56, 235.

https://doi.org/10.1016/S0065-2318(01)56006-0

38. Manabe, S.; Ito, Y. J. Am. Chem. Soc. 1999, 121, 9754.

https://doi.org/10.1021/ja990926a

39. Hosomi, A.; Sakata, Y.; Sakurai, H. Tetrahedron Lett. 1984, 25, 2383.

https://doi.org/10.1016/S0040-4039(01)80261-6

40. Hosomi, A.; Sakata, Y.; Sakurai, H. Carbohydr. Res. 1987, 171, 223. https://doi.org/10.1016/S0008-6215(00)90889-9

41. Giannis, A.; Sandhoff, K. Tetrahedron Lett. 1985, 26, 1479.

https://doi.org/10.1016/S0040-4039(00)98529-0

42. Sail, D.; Kováč, P. Carbohydr. Res. 2012, 357, 47. https://doi.org/10.1016/j.carres.2012.05.012

43. Jamshaid, F., Synthesis towards new C-glycoside derivatives of multivalent carbohydrates. 2012. https://www.research.manchester.ac.uk/portal/files/54524258/FULL TEXT.PDF

44. Bennek, J. A.; Gray, G. R. J. Org. Chem. 1987, 52, 892.

https://doi.org/10.1021/jo00381a030

45. Granovsky, A. A. Firefly version 8.

http://www.classic.chem.msu.su/gran/firefly/index.html 
46. O'Boyle, N. M.; Tenderholt, A. L.; Langner, K. M. J. Comp. Chem. 2008, 29, 839. https://doi.org/10.1002/jcc.20823

47. De Ruyck, J.; Lensink, M. F.; Bouckaert, J. IUCrJ 2016, 3, 163. https://doi.org/10.1107/S2052252516002487 